\title{
PEMANFAATAN POHON BERKHASIAT OBAT DI CAGAR ALAM GUNUNG PICIS DAN GUNUNG SIGOGOR, KABUPATEN PONOROGO, JAWA TIMUR
}

\section{(The Utilization of Medicinal Trees in Mount Picis and Mount Sigogor Nature Reserves, District of Ponorogo, East Java Province)*}

\author{
Oleh/By: \\ Titiek Setyawati \\ Pusat Litbang Hutan dan Konservasi Alam \\ Jl. Gunung Batu No. 5 Po Box 165; Telp. 0251-8633234, 7520067; Fax 0251-8638111 Bogor \\ e-mail: titiek29@yahoo.com \\ *Diterima : 22 Oktober 2007; Disetujui : 19 Mei 2010
}

\begin{abstract}
Research acquiring information concerning the utilization of medicinal trees was carried out in two nature reserves areas located in the District of Ponorogo, East Java Province. Data collection was conducted through direct observation in the field, interview with local people, and literature study. Based on literature study, there were 12 species of medicinal trees recorded in Mount Picis and Mount Sigogor nature reserves: suren (Toona sinensis M. Roem.), puspa (Schima wallichii Korth.), morosowo (Engelhardtia spicata Bl.), talesan (Persea odoratissima Kosterm.), gitri (Elaeocarpus sphaericus K. Schum.), mangir (Ganophyllum falcatum Bl.), cempaka (Turpinia sphaerocarpa Hassk.), trawas (Litsea odorifera T. et B.), nyampuh (Pygeum parviflorum T. et B.), kayu abang (Payena lerii Kurz.) pasang (Castanopsis acuminatissima A. DC), and pasang biasa (Lithocarpus elegans (Bl) Hatus). Five out of these 12 species are utilized by local people for medicine, they are: puspa, morosowo, talesan, mangir, and kayu abang. The potency of medicinal trees recorded in the research sites are relatively high. Unfortunately, only few has been recognized and utilized by local people for traditional healing. For local people, modern medicine currently available in traditional market is more attractive than the traditional medicine due to easy access and cheap price.
\end{abstract}

Keywords: Nature reserves, medicinal trees, traditional healing

\begin{abstract}
ABSTRAK
Kegiatan penelitian untuk mengumpulkan informasi tentang pemanfaatan pohon obat dilakukan di dua lokasi cagar alam di Kabupaten Ponorogo, Provinsi Jawa Timur. Pengumpulan data dan informasi ini diperoleh melalui pengamatan langsung di lapangan, wawancara langsung dengan penduduk lokal serta melalui studi pustaka. Berdasarkan hasil penelitian yang dilakukan di Cagar Alam Gunung Picis dan Gunung Sigogor di Kabupaten Ponorogo, Jawa Timur, ditemukan 12 jenis pohon berkhasiat obat yang diketahui berdasarkan kajian pustaka yaitu suren (Toona sinensis M. Roem.), puspa (Schima wallichii Korth.), morosowo (Engelhardtia spicata Bl.), talesan (Persea odoratissima Kosterm.), gitri (Elaeocarpus sphaericus K. Schum.), mangir (Ganophyllum falcatum Bl.), cempaka (Turpinia sphaerocarpus Hassk.), trawas (Litsea odorifera T. et B.), nyampuh (Pygeum parviflorum T. et B.), kayu abang (Payena lerii Kurz.), pasang (Castanopsis acuminatissima A. DC), dan pasang biasa (Lithocarpus elegans (Bl) Hatus). Dari 12 jenis ini hanya ada lima jenis saja yang berdasarkan wawancara dimanfaatkan oleh penduduk sebagai bahan obat yaitu puspa, morosowo, talesan, mangir, dan kayu abang. Potensi dari jumlah pohon berkhasiat obat yang ditemukan di lokasi penelitian cukup tinggi. Sayangnya masyarakat yang berada di sekitar lokasi penelitian memanfaatkan hanya sebagian saja untuk pengobatan tradisional. Masyarakat lebih memilih untuk menggunakan obat-obatan modern (non-tradisional) yang mudah diperoleh dengan harga murah di pasarpasar lokal.
\end{abstract}

Kata kunci: Cagar alam, pohon berkhasiat obat, pengobatan tradisional 


\section{PENDAHULUAN}

Indonesia terkenal sangat kaya akan keanekaragaman jenis tumbuhan hutan, di antaranya 4.000 jenis atau lebih berupa pohon (Sastrapradja et al., 1989). Di Jawa terdapat sekitar 500 jenis pohon hutan (Bagian Botani Hutan, 1976 dan 1977), sedangkan di Sumatera sekitar 1.200 jenis pohon (Whitmore dan Tantra, 1986). Di antara jenis-jenis pohon hutan tersebut berpotensi sebagai bahan baku obat-obatan yang dianggap sebagai produk hasil hutan non-kayu. Adapun pemanfaatan tumbuhan hutan sebagai tumbuhan obat yang sebagian besar digunakan untuk obat tradisional saat ini sudah demikian banyaknya (dari lebih 1.000 jenis yang dipakai, 74\% di antaranya tumbuh liar di hutan) (Amzu dan Haryanto, 1991). Saat ini tercatat sejumlah 283 jenis tumbuhan yang telah digunakan dalam ramuan obat tradisional dan 180 jenis di antaranya berasal dari hutan hujan tropika (Ditjen POM, 1991) sedangkan Departemen Kesehatan Republik Indonesia/DEPKES-RI (1989) mencatat sejumlah 119 jenis yang 49 di antaranya merupakan pohon kayu komersial (Sumarna, 2001).

Sudah banyak informasi mengenai jenis dan pemanfaatan tumbuhan obat (Widjayakusuma, 2000, Tjitrosoepomo, 2005, Widjayakusuma et al., 1996, Hutton, 1997), namun demikian hampir seluruhnya membahas tumbuhan non-kayu terutama tumbuhan bawah, seperti semak dan perdu. Penelitian menyangkut jenisjenis pohon berkhasiat obat telah dilakukan di beberapa kawasan hutan, baik di Jawa maupun di luar Jawa (Jafarsidik dan Soetarto, 1980, Jafarsidik dan Sutomo, 1986) namun penelitian terbatas hanya pada inventarisasi, deskripsi jenis, dan pemanfaatannya berdasarkan informasi dari masyarakat yang menggunakannya dan belum sampai pada taraf uji bahan aktif kandungan senyawa kimia serta tahap akhir uji klinis untuk mengetahui manfaatnya sebagai bahan pengobatan. Salah satu penyebab minimnya informasi secara lengkap tentang pohon berkhasiat obat adalah keterbatasan biaya yang diperlukan untuk melakukan kajian lengkap untuk jenis-jenis pohon di hutan alam serta biaya untuk melakukan uji bahan aktif kandungan kimia yang umumnya relatif mahal.

Pengetahuan menyangkut jenis-jenis pohon berkhasiat obat di Indonesia saat ini semakin diperlukan mengingat pentingnya tujuan peningkatan pengelolaan dan pemanfaatan hutan masa kini. Dalam rangka upaya mempertahankan fungsi hutan alam, saat ini sedang diupayakan pemanfaatan dan pembinaan berbagai jenis tumbuhan di antaranya adalah jenis-jenis pohon berkhasiat obat yang terdapat di dalam kawasan hutan. Pengetahuan tentang pemanfaatan tumbuhan obat juga merupakan warisan budaya bangsa yang diperoleh berdasarkan pengetahuan dan pengalaman yang diwariskan secara turun-temurun (Widjayakusuma, 2000). Namun demikian, data menyangkut potensi dan persebaran jenis-jenis berkhasiat obat yang ada di kawasan hutan alam di Indonesia masih sangat minim. Tujuan penelitian ini adalah untuk memperoleh data dan mengungkap informasi tentang keanekaragaman jenis, potensi, permasalahan di lapangan, dan pemanfaatan jenisjenis pohon berkhasiat obat yang ada di hutan Indonesia.

\section{METODOLOGI}

\section{A. Waktu dan Lokasi Penelitian}

Penelitian lapangan di kawasan hutan Cagar Alam (CA) Gunung Sigogor dan Gunung Picis, di Kabupaten Ponorogo dilakukan pada bulan September tahun 2006. Waktu pengamatan lapangan yaitu selama 12 hari. Bahan yang dijadikan sebagai obyek penelitian adalah semua jenis pohon berkhasiat obat yang merupakan tanaman asli setempat yang terdapat di kawasan hutan alam dan penduduk (sebagai responden) yang tinggal di desa 
sekitar hutan cagar alam yang ada di Provinsi Jawa Timur. Lokasi penelitian tertera pada Gambar 1.

Keberadaan kedua kawasan lindung tersebut dikuatkan secara hukum sejak sebelum Indonesia merdeka pada tahun 1945, yakni kawasan lindung CA Gunung Picis oleh SK GB No. 36 Stbl. No. 43, 4 Pebruari 1924 dan CA Gunung Sigogor oleh SK GB No. 23 Stbl. 471, 4 September 1936. Kedua lokasi terletak di Kecamatan Ngebel yang berbatasan dengan hutan lindung dan hutan produksi milik Perum Perhutani. Pengelolaan kawasan CA Gunung Picis di bawah Balai Konservasi Sumber Daya Alam (BKSDA) IV sedangkan CA Gunung Sigogor di bawah BKSDA I Jawa Timur. Luas CA Gunung Sigogor yaitu 190,5 ha sedangkan CA Gunung Picis adalah 27,90 ha. Gunung Sigogor memiliki topografi berbukit-bukit terutama lokasi yang ada di lereng barat Gunung Wilis dengan medan berlereng sedang hingga curam pada ketinggian 100-1.700 m dpl. Hampir sama dengan Gunung Sigogor, Gunung Picis bertopografi sedang hingga curam dengan kelerengan antara 40-60\% serta terletak pada ketinggian $\pm 1.200 \mathrm{~m}$ dpl.

Cagar Alam Gunung Sigogor dan Gunung Picis memiliki formasi geologis yang hampir sama dengan batuan vulkanik muda dan jenis tanah yang masuk dalam kompleks mediteran. Tipe tanah di Gunung Sigogor adalah litosol sedangkan di Gunung Picis kombinasi grumusol dan latosol. Iklim di kedua lokasi masuk dalam tipe $\mathrm{C}$ dengan nilai Q $=57 \%$ (Schmidt dan Ferguson, 1951). Curah hujan rata-rata di Gunung Picis dan Gunung Sigogor yaitu 2647 mm/th dan 2582 $\mathrm{mm} /$ th dengan jumlah hari hujan 147 hari dan 142 hari. Suhu di kedua lokasi berkisar antara $15-20^{\circ} \mathrm{C}$ pada malam hari dan antara $30-35^{\circ} \mathrm{C}$ pada siang hari.

Tipe ekosistem kedua lokasi adalah hutan hujan tropis pegunungan. Vegetasi di Gunung Picis didominasi oleh morosowo (Engelhardia spicata Bl.), pasang (Quercus sundaica Bl.), dali (Radermachera gigantea (Bl.) Miq.), nyampuh (Litsea glutinosa (Lour) C.D.), dan pulus (Laportea stimulans (L.F) Gaud ex. Midd.); sedangkan vegetasi di Gunung Sigogor didominasi oleh pasang (Quercus sundaica $\mathrm{Bl}$.), jamuju (Podocarpus

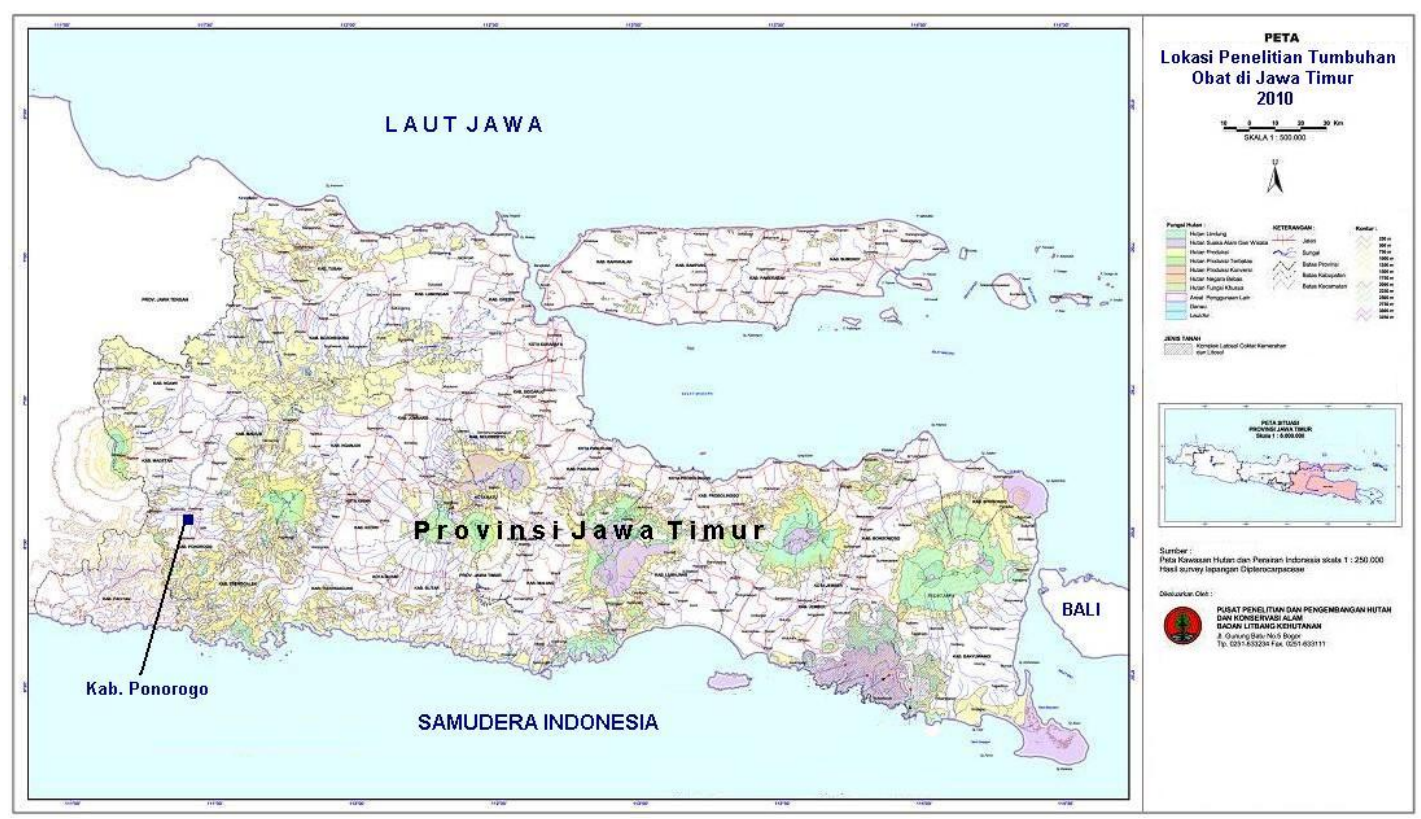

Gambar (Figure) 1. Lokasi penelitian di Kabupaten Ponorogo, Provinsi Jawa Timur (Map of research location in the Disctrict of Ponorogo, East Java Province) 
imbricatus Blume), rasamala (Altingia excelsa Noronhae), dali (Radermachera gigantea (Bl.)Miq.), wesen (Dodonaea viscosa (L) Jaca.), kodokan (Macropanax dispermum Kuntze), morosowo (Engelhardia spicata $\mathrm{Bl}$.), embacang (Mangifera foetida Lour), puspa (Schima walichii Korth.), salam (Eugenia Polyantha Wight.), dan lain-lain.

\section{B. Metode Penelitian}

Kegiatan pengamatan dan pengumpulan data lapangan antara lain dilakukan dengan cara:

1. Pengumpulan data, baik secara langsung (data primer) melalui wawancara dengan masyarakat yang tinggal di dekat dan sekitar hutan maupun tidak langsung (data sekunder) dengan cara pengumpulan data monografi desa, data lokasi, dan kajian daftar pustaka.

2. Pengambilan sampel responden dilakukan secara seleksi dan acak. Jumlah responden yang diambil sebanyak 15 responden (dua responden pengobat tradisional, 13 responden pengguna atau penduduk lokal yang di sampel secara acak) untuk masing-masing lokasi pengamatan (satu desa di Gunung Picis dan satu desa di Gunung Sigogor). Kuesioner dipersiapkan sebelum kegiatan lapangan dilakuka dan digunakan untuk bahan wawancara dengan penduduk. Kuesioner memuat pertanyaan-pertanyaan menyangkut berbagai macam informasi kegunaan, bahan ramuan, dan manfaat jenis-jenis pohon yang berkhasiat obat. Hasil kuesioner kemudian diolah untuk mendapatkan informasi tingkat pemanfaatan jenis pohon berkhasiat obat oleh penduduk.

3. Pengamatan keanekaragaman jenis pohon berkhasiat obat dan kondisi lingkungan tempat tumbuhnya dengan menggunakan metode eksplorasi dalam jalur-jalur yang sistematik. Panjang tiap jalur eksplorasi yaitu satu km dengan jarak antar jalur $500 \mathrm{~m}$ dan jumlah jalur disesuaikan dengan kon- disi topografi lokasi pengamatan. Beberapa sampel pohon diambil untuk keperluan identifikasi dan koleksi herbarium. Untuk itu digunakan blanko isian mencakup data pohon, data kondisi lingkungan tempat tumbuh, dan data penggunaan tradisional penduduk setempat.

4. Pendugaan potensi dengan menggunakan metode titik pusat kuadran (quadrant center point method) sepanjang jalur eksplorasi dengan jarak antara titik pertama dan titik berikutnya $50 \mathrm{~m}$. Pada tiap titik pusat kuadran dilakukan perisalahan empat individu pohon berkhasiat obat atau pohon lainnya yang terdekat dengan titik pusat, atau satu individu pohon pada tiap kuadran. Individu pohon tersebut yang dirisalah dibatasi jarak terjauh $25 \mathrm{~m}$ dari titik pusat kuadran dan diameter batangnya $20 \mathrm{~cm}$ atau lebih. Pendataan pohon meliputi nama jenis, diameter batang, dan tinggi pohon.

5. Identifikasi jenis dan proses koleksi herbarium pohon berkhasiat obat yang diperoleh dari kegiatan eksplorasi disertai dengan deskripsinya. Identifikasi dilakukan di Laboratorium Botani dan Ekologi Hutan, Pusat Penelitian dan Pengembangan Hutan dan Konservasi Alam, Bogor.

\section{Analisis Data}

Beberapa definisi dan kalkulasi yang digunakan dalam analisis vegetasi antara lain:

1. Kepadatan, yaitu jumlah individu per plot $\left(100 \mathrm{~m}^{2}\right)$.

2. Frekuensi, yaitu jumlah unit sampel $(10 \mathrm{~m} \times 10 \mathrm{~m})$ di mana jenis ditemukan.

3. Luas Bidang Dasar (LBD), yaitu luasan bagian melintang batang pohon berdiameter di atas $20 \mathrm{~cm}$ yang diukur pada ketinggian sebatas dada (diameter of breast height/dbh). LBD tiap pohon diperoleh dengan menggunakan rumus: $\operatorname{LBD}\left(\mathrm{m}^{2}\right)=1 / 4 \pi \mathrm{d}^{2}$ (Kent dan 
Coker, 1992), dimana $\pi=$ phi atau 3,14, dan $d=$ diameter batang.

4. Indeks Nilai Penting (INP): perkiraan secara keseluruhan pentingnya suatu jenis pohon di dalam komunitas lokalnya. Nilai INP ini diperoleh dengan cara menjumlahkan Dominansi Relatif (DR), Kepadatan Relatif (KR), dan Frekuensi Relatif (FR) dari jenis tertentu. Dominansi relatif merupakan rasio total luas bidang dasar dari suatu jenis terhadap jumlah total luas bidang dasar dari seluruh jenis yang ada, KR merupakan rasio jumlah individu dari suatu jenis terhadap jumlah total jenis di dalam plot, dan FR merupakan rasio frekuensi dari suatu jenis terhadap total frekuensi seluruh jenis di dalam plot. Angka atau nilai INP total mencapai 300\% (Kent dan Coker, 1992; Krebs, 1999 dan 1994).

5. Penyusunan pemanfaatan jenis pohon berkhasiat obat yang digunakan oleh masyarakat setempat berdasarkan hasil wawancara. Penilaian ditentukan dengan melakukan pembobotan terhadap frekuensi pemanfaatan: sering (25), kadang/jarang (10), dan tidak/belum digunakan (5). Masing-masing responden akan memberikan informasi setiap jenis pohon berkhasiat obat yang ditemukan di lapangan.

\section{III.HASIL DAN PEMBAHASAN}

\section{A. Komposisi Jenis Pohon Berkhasiat Obat}

Total jumlah jenis pohon hutan yang ditemukan pada plot transek pengamatan yaitu sebanyak 31 jenis (dihitung dari semua tingkatan, baik semai, pancang, tiang, dan pohon). Jumlah jenis pohon yang diinvetarisir di CA Gunung Sigogor adalah 21 jenis (Lampiran 1) sedangkan di Gunung Picis 10 jenis (Lampiran 2). Untuk jumlah jenis pohon di atas diameter $10 \mathrm{~cm}$ sebanyak 12 jenis pohon di CA Gunung Sigogor dan tujuh jenis di CA Gunung Picis. Dengan demikian, total jumlah jenis pohon (diameter $>10 \mathrm{~cm}$ ) yaitu sebanyak 19 jenis. Dari ke-19 jenis pohon yang diinventarisir di Kabupaten Ponorogo tersebut, jumlah total jenis yang berkhasiat obat adalah 12 jenis (11 jenis ditemukan di CA Gunung Sigogor dan lima jenis ditemukan di CA Gunung Picis). Dari 11 jenis ini yaitu suren (Toona sinensis M. Roem.), puspa (Schima wallichii Korth.), morosowo (Engelhardtia spicata $\mathrm{Bl}$.), talesan (Persea odoratissima Kosterm.), gitri (Elaeocarpus sphaericus K. Schum.), mangir (Ganophyllum falcatum $\mathrm{Bl}$.), pasang biasa ( $\mathrm{Li}$ thocarpus elegans Bl.), cempaka (Turpinia sphaerocarpus Hassk.), tawas (Litsea odorifera T. et B.), nyampuh (Pygeum parviflorum $\mathrm{T}$. et B.), dan kayu abang (Payena lerii Kurz.), hanya ada lima jenis yang dimanfaatkan oleh penduduk yaitu puspa, morosowo, talesan, mangir, dan kayu abang. Dari lima jenis pohon obat yang ada di Gunung Picis yaitu puspa (Schima wallichii Korth.), morosowo (Engelhardtia spicata Bl.), talesan (Persea odoratissima Kosterm.), pasang biasa (Lithocarpus elegans Bl.), dan pasang rebung (Castanopsis acuminatissima A.D.C), empat jenis sudah dimanfaatkan oleh penduduk, yaitu pasang biasa, morosowo, puspa, dan talesan. Hampir semua jenis pohon berkhasiat obat yang ada di Gunung Picis ini juga ditemukan di CA Gunung Sigogor, kecuali pasang rebung.

Di CA Gunung Sigogor, Kabupaten Ponorogo, ada lima jenis pohon berkhasiat obat yang memiliki INP cukup tinggi (Lampiran 3) yaitu: Persea odoratissima Kosterm (81,16\%), Payena leerii Kurz. (52,66), Engelhardtia spicata $\mathrm{Bl}$. (31,29\%), Litsea odorifera $\mathrm{T}$ et $\mathrm{B}$. (47,26\%), dan Lithocarpus elegans $\mathrm{Bl}$. $(25,87 \%)$. Sementara itu INP jenis pohon berkhasiat obat yang ada di CA Gunung Picis (Lampiran 4) juga memiliki nilai INP yang tinggi antara lain: Castanopsis acuminatissima A.D.C. (146,24\%), Schima walichii Korth. (45,07\%), Engelhardtia spicata Bl. (40,96\%), Lithocarpus ele- 
gans $\mathrm{Bl}$. (23,97\%), dan Persea odoratissima Kosterm. (22,51\%). Gambaran dari profil jenis pohon berkhasiat obat yang memiliki INP cukup tinggi yang ditemukan di CA Gunung Sigogor tertera pada Gambar 2.

Untuk tingkat pohon (trees), talesan (Persea odoratissima Kosterm.) di CA Gunung Sigogor memiliki nilai INP sebesar $81,16 \%$ yang hampir empat kali lebih tinggi dibandingkan dengan yang ditemukan di CA Gunung Picis yaitu 22,51\%. Namun sebaliknya, puspa (Schima walichii Korth.) di CA Gunung Picis memiliki nilai INP yang jauh lebih tinggi dibandingkan dengan puspa yang ada di CA Gunung Sigogor yaitu berturut-turut 134,04\% dengan 17\%. Sementara itu pasang rebung (Castanopsis acuminatissima A.D.C) memiliki INP mencapai $146,24 \%$ di CA Gunung Picis namun tidak ditemukan di Gunung Sigogor (Lampiran 3 dan Lampiran 4). Hal yang demikian dimungkinkan oleh adanya perbedaan tipe tanah serta persaingan dalam masa pertumbuhan masing-masing jenis, dimana masing-masing jenis memiliki persyaratan hidup yang berbeda.

\section{B. Uraian Jenis-jenis Pohon Berkha- siat Obat}

Beberapa jenis pohon yang berpotensi sebagai bahan baku obat yang ditemukan selama penelitian di Kabupaten Ponorogo tertera pada Tabel 1. Namun demikian dari sejumlah banyak pohon berkhasiat obat yang tumbuh di kawasan hutan tersebut hanya beberapa jenis saja yang sudah dimanfaatkan oleh masyarakat. Jenisjenis pohon obat yang ditemukan di Kabupaten Ponorogo tersebut dijelaskan secara umum dalam Tabel 1.

Berikut adalah informasi tentang morfologi, habitus dan cara pemanfaatan ke12 jenis pohon obat yang ditemukan di lapangan:

\section{Suren (Toona sinensis M. Roem.) - Meliaceae}

Kulit batang yang pahit yang berwarna merah dicampur dengan Acorus calamus Linn. dan air, lalu air perasannya diminum untuk mengurangi demam, sakit perut, dan disentri. Kulitnya dapat dibuat bubur (dicampur dengan pucuk daun suren dan pulosari), dioleskan pada bagian perut yang bengkak untuk mengurangi

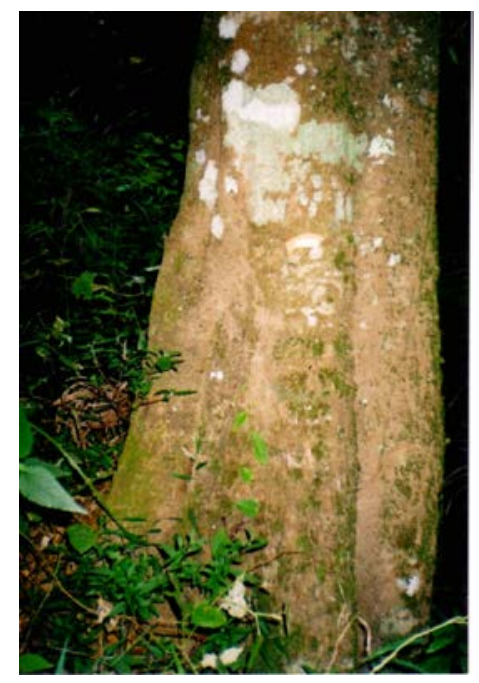

Talesan

(Persea odoratissima Kosterm.)
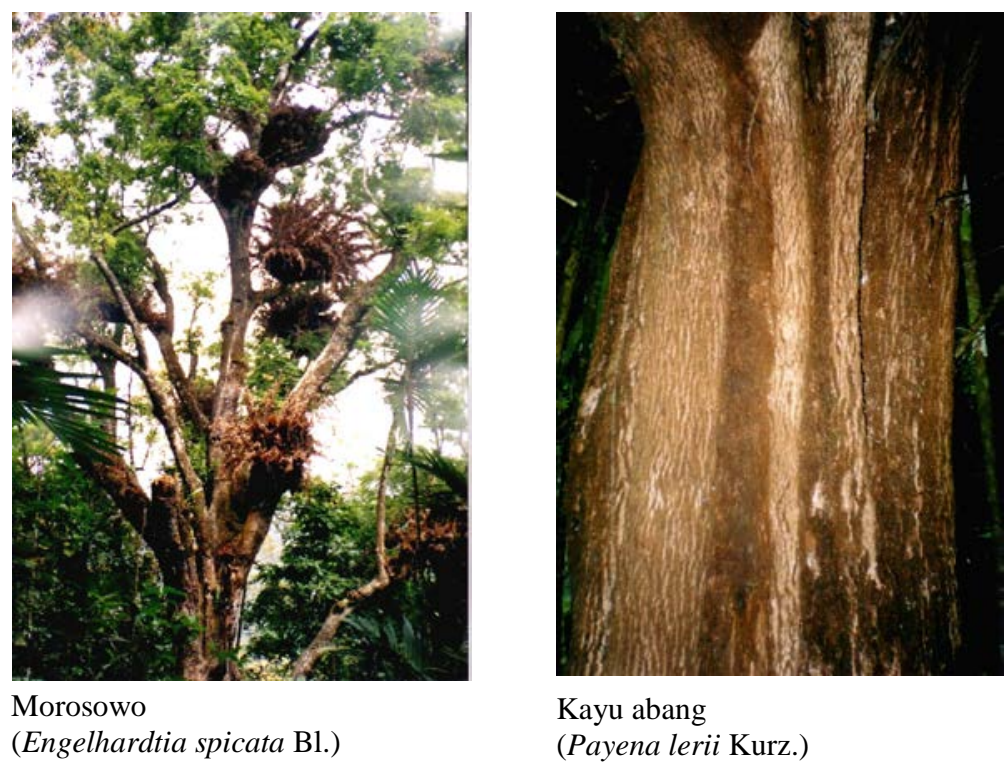

Kayu abang

(Payena lerii Kurz.)

Gambar (Figure) 2. Beberapa jenis pohon berkhasiat obat yang memiliki nilai INP relatif tinggi di CA Gunung Sigogor, Kabupaten Ponorogo, Jawa Timur (Some medicinal tree species with high Important Index Value recorded in Mt. Sigogor Nature Reserve, Ponorogo District, East Java) 
Tabel (Table) 1. Daftar jenis tumbuhan obat yang ditemukan di Gunung Sigogor dan Gunung Picis, Kabupaten Ponorogo, Jawa Timur (List of local medicinal tree species recorded in Mt. Sigogor and Mt. Picis, District of Ponorogo, East Java)

\begin{tabular}{|c|c|c|c|c|c|c|}
\hline No. & $\begin{array}{c}\text { Nama botani } \\
\text { (Botanical name) }\end{array}$ & Suku (Family) & $\begin{array}{l}\text { Nama } \\
\text { daerah } \\
\text { (Local } \\
\text { name) }\end{array}$ & $\begin{array}{l}\text { Bagian yang } \\
\text { digunakan* } \\
\text { (Part used) }\end{array}$ & $\begin{array}{l}\text { Kandungan } \\
\text { kimia* } \\
\text { (Chemical } \\
\text { content) }\end{array}$ & $\begin{array}{c}\text { Khasiat/ } \\
\text { manfaat* } \\
\text { (Uses) }\end{array}$ \\
\hline 1. & $\begin{array}{l}\text { Toona sinensis M. } \\
\text { Roem }\end{array}$ & Meliaceae & Suren & Kulit batang & $\begin{array}{l}\text { Zat samak, } \\
\text { getah, dan } \\
\text { zat pahit }\end{array}$ & $\begin{array}{l}\text { Astringen, } \\
\text { tonikum } \\
\text { untuk diare } \\
\text { dan disentri, } \\
\text { demam, } \\
\text { ginjal } \\
\text { bengkak }\end{array}$ \\
\hline 2. & $\begin{array}{l}\text { Schima wallichii } \\
\text { Korth. }\end{array}$ & Theaceae & Puspa & Kulit batang & $\begin{array}{l}\text { Saponin, } \\
\text { glycoside }\end{array}$ & $\begin{array}{l}\text { Otitis, } \\
\text { sengatan } \\
\text { ikan }\end{array}$ \\
\hline 3. & $\begin{array}{l}\text { Engelhardtia } \\
\text { spicata } \mathrm{Bl} \text {. }\end{array}$ & Juglandaceae & Morosowo & Kulit batang & $* *$ & $\begin{array}{l}\text { Gatal di } \\
\text { kulit }\end{array}$ \\
\hline 4. & $\begin{array}{l}\text { Persea } \\
\text { odoratissima } \\
\text { Kosterm. }\end{array}$ & Lauraceae & Talesan & Daun & $* *$ & Bisul \\
\hline 5. & $\begin{array}{l}\text { Elaeocarpus } \\
\text { sphaericus K. } \\
\text { Schum. }\end{array}$ & Elaeocarpaceae & Gitri & $\begin{array}{l}\text { Daun, kulit } \\
\text { batang }\end{array}$ & $* *$ & $\begin{array}{l}\text { Obat sakit } \\
\text { perut, sakit } \\
\text { di dada dan } \\
\text { bahu }\end{array}$ \\
\hline 6. & $\begin{array}{l}\text { Ganophyllum } \\
\text { falcatum Bl. }\end{array}$ & Sapindaceae & Mangir & Kulit batang & & $\begin{array}{l}\text { Pencuci } \\
\text { rambut }\end{array}$ \\
\hline 7. & $\begin{array}{l}\text { Litsea odorifera } \\
\text { T. et B. }\end{array}$ & Lauraceae & Trawas & Daun & $\begin{array}{l}\text { Minyak } \\
\text { atsiri, } \\
\text { damar, dan } \\
\text { tanin }\end{array}$ & $\begin{array}{l}\text { Penambah } \\
\text { nafsu } \\
\text { makan, } \\
\text { karminatif, } \\
\text { sariawan, } \\
\text { pelancar } \\
\text { ASI, dan } \\
\text { obat bisul }\end{array}$ \\
\hline 8. & $\begin{array}{l}\text { Pygeum } \\
\text { parviflorum } \\
\text { Teisjm. \& } \\
\text { Binnend }\end{array}$ & Rosaceae & $\begin{array}{l}\text { Nyampuh/ } \\
\text { moyang }\end{array}$ & Kulit batang & Pahitan & $* *$ \\
\hline 9. & $\begin{array}{l}\text { Payena leerii } \\
\text { Kurz. }\end{array}$ & Sapotaceae & $\begin{array}{l}\text { Kayu } \\
\text { abang }\end{array}$ & $* *$ & Getah damar & $* *$ \\
\hline 10. & $\begin{array}{l}\text { Turpinia } \\
\text { sphaerocarpus } \\
\text { Hassk. }\end{array}$ & Staphyleaceae & Cempaka & $* *$ & Alkaloids & $* *$ \\
\hline 11. & $\begin{array}{l}\text { Castanopsis } \\
\text { acuminatissima A. } \\
\text { DC }\end{array}$ & Fagaceae & $\begin{array}{l}\text { Pasang } \\
\text { robyong }\end{array}$ & $* *$ & Zat samak & $* *$ \\
\hline 12. & $\begin{array}{l}\text { Lithocarpus } \\
\text { elegans (Bl) } \\
\text { Hatus. }\end{array}$ & Lithocarpaceae & & $\begin{array}{l}\text { Kulit batang, } \\
\text { biji }\end{array}$ & $\begin{array}{l}\text { Lupeol dan } \\
\text { betulinic } \\
\text { acid }\end{array}$ & $* *$ \\
\hline
\end{tabular}

* Informasi bagian yang digunakan, kandungan kimia, dan khasiat dari setiap jenis pohon diperoleh melalui studi pustaka (Sumarna, 2001, PROSEA, 2001 dan Heyne, 1987) dan informasi yang diperoleh, baik melalui wawancara maupun website (Information regarding to part uses, chemical contents, and uses of each tree obtained from literature reviews (Sumarna, 2001, PROSEA, 2001 and Heyne, 1987) and information obtained through interview and website)

** Informasi tidak tersedia (Information is unavailable) 
pembengkakan pada limpa. Pohon yang termasuk cepat tumbuh ini, di alam tingginya dapat mencapai $35-40 \mathrm{~m}$ dengan diameter batang mencapai 2-3 $\mathrm{m}$. Umum ditemukan di Jawa pada ketinggian terutama di bawah $1.200 \mathrm{~m}$, meskipun juga bisa ditemukan pada ketinggian $2.000 \mathrm{~m}$ (Heyne, 1987).

\section{Puspa (Schima wallichii Korth.) - Theaceae}

Gelam kayu, daun dan bunganya mengandung glycosida (saponin). Bunganya dibuat ramuan atau rempah-rempah sebagai campuran obat. Buahnya juga digunakan sebagai obat. Berdasarkan wawancara dengan penduduk selama penelitian di Gunung Sigogor, masyarakat memanfaatkan daunnya untuk mengobati sakit perut dan diare (Tabel 2). Pohon sangat tinggi $(30 \mathrm{~m})$ dan bertajuk lebat. Tumbuh pada ketinggian 250 hingga 2.600 m dpl (Heyne, 1987).

\section{Morosowo (Engelhardtia spicata Bl.) - Juglandaceae}

Informasi serta literatur menyangkut pemanfaatannya sebagai ramuan untuk obat-obatan tidak ditemukan. Namun demikian jenis ini tercantum dalan daftar tumbuhan obat hutan tropika di Indonesia (Sumarna, 2001). Berdasarkan hasil wawancara dengan penduduk lokal di lokasi penelitian Gunung Sigogor dan Gunung Picis, masyarakat memanfaatkan kulit batangnya untuk mengobati gatal-gatal pada kulit (Tabel 2). Pohon dengan tinggi mencapai $30 \mathrm{~m}$ dan diameter 1-1,5 m ini tersebar di seluruh Asia Tenggara. Di Jawa tumbuh pada ketinggian 200-1.000 m dpl (Heyne, 1987).

\section{Talesan (Persea odoratissima Kos- term.) - Lauraceae}

Schlemper et al. (2001) menemukan bahan yang mengandung anti bakteri pada daging buahnya. Penduduk di Gunung Sigogor menggunakannya sebagai obat untuk mengurangi bengkak-bengkak bernanah atau bisul berdasarkan pengalaman dan kebiasaan. Pohon dengan tinggi antara 14-40 m dengan arsitektur yang indah. Di Jawa tumbuh pada ketinggian 7001.200 m dpl (Heyne, 1987).

\section{Gitri (Elaeocarpus sphaericus K.} Schum.) - Elaeocarpaceae

Daun dan kulit batangnya digunakan untuk mengobati sakit perut, sakit di dada dan pundak (PROSEA, 2001). Daging buahnya dapat dimakan (Heyne, 1987). Pohon dengan tinggi mencapai $25-30 \mathrm{~m}$ dan besar batang 30-40 cm tumbuh tersebar di Asia Tenggara, dan di Jawa tumbuh pada ketinggian kurang dari $1.200 \mathrm{~m}$ dpl. Di Jawa Timur umumnya tumbuh pada ketinggian $350 \mathrm{~m}$ dpl.

\section{Mangir (Ganophyllum falcatum Bl.) - Sapindaceae}

Kulit batang diseduh air panas dan digunakan untuk menghilangkan kutu rambut dan juga digunakan sebagai pengganti sabun. Di alam tumbuh besar dengan tinggi mencapai $40 \mathrm{~m}$ dan besar batang 1,5 m. Umumnya tumbuh tersebar pada ketinggian kurang dari $800 \mathrm{~m}$ dpl. (Heyne, 1987).

\section{Cempaka (Turpinia sphaerocarpa Hassk.) - Staphyleaceae}

Pemanfaatannya untuk bahan obat tidak diketahui secara ilmiah namun disebutkan termasuk dalam tumbuhan obat (Sumarna, 2001). Bagian kulit mengandung alkaloids (Safitri, 1995). Pohon dengan tinggi sampai $20 \mathrm{~m}$ dan besar batangnya $60 \mathrm{~cm}$ tumbuh tersebar di Asia Tenggara. Umumnya di Jawa hidup pada ketinggian 200-1.750 m dpl. (Heyne, 1987).

\section{Trawas (Litsea odorifera T. et B.) - Lauraceae}

Daun dikeringkan dan digunakan sebagai obat dengan nama dagang daun trawas. Daun mengandung minyak atsiri. Daun dicampur dengan kunyit dan gula digunakan untuk mengobati sariawan. Untuk obat penyakit empedu, daun 
direbus dan dicampur dengan temu lawak. Untuk menambah jumlah air susu ibu (ASI), daun diremas-remas lalu dioleskan pada payudara ibu yang menyusui. Remasan daun dicampur dengan kapur dapat mengobati bisul. Daun dicampur dengan mungsi dan ketumbar dapat digunakan untuk obat sakit perut (dioleskan ke perut). Pohon dengan tinggi sedang ini berbau harum pada setiap bagian pohonnya. Tumbuh di seluruh nusantara (Heyne, 1987).

\section{Nyampuh (Pygeum parviflorum Teisjm. \& Binnend) - Rosaceae}

Kulit batangnya pahit dan digunakan sebagai obat (dalam pustaka tidak disebutkan jenis pengobatannya). Pohon dengan tinggi sampai $25 \mathrm{~m}$ dan diameter 60 $\mathrm{cm}$. Di Jawa Barat tumbuh di ketinggian 300-1.500 m dpl. (Heyne, 1987).

\section{Kayu Abang (Payena lerii Kurz.) - Sapotaceae}

Meskipun mengandung getah damar dan buahnya dapat dimakan dan bijinya mengandung minyak, namun pustaka (Heyne, 1987) tidak menyebutkan pemanfaatannya sebagai bahan ramuan obat. Namun jenis ini masuk dalam daftar plasma nutfah tumbuhan obat koleksi kebun percobaan Balai Penelitian Tanaman Rempah dan Obat (Balittro) (Hadad dan Rostiana, 1991). Penduduk di lokasi penelitian (Gunung Picis dan Gunung Sigogor) memanfaatkan daunnya untuk mengobati diare dan sakit perut. Pohon tinggi mencapai $38 \mathrm{~m}$ dan diameter 70 $\mathrm{cm}$ dan tumbuh di hutan tanah kering (Heyne, 1987).

\section{Pasang Robyong (Castanopsis acu- minatissima A. DC) - Fagaceae}

Khan et al. (2001) menemukan bahan yang mengandung antimikroba di kulit pohon pasang. Penduduk di lokasi penelitian menggunakan buahnya yang terasa pahit untuk obat sakit perut. Dalam Heyne (1987) disebutkan kulitnya mengandung bahan samak.

\section{Pasang Biasa (Lithocarpus elegans (Bl) Hatus.) - Lithocarpaceae}

Tidak ditemukan pustaka yang membahas pemanfaatan jenis pohon ini untuk bahan obat-obatan. Namun demikian Chowwanapoonpohn et al. (2005) menemukan bahan kandungan kimia aktif jenis lupeol dan asam betulinic yang secara medis dapat menekan laju penyebaran kanker leher, sedangkan asam betulinic digunakan untuk mencegah tumor dan penyakit malaria.

\section{Jenis yang Dimanfaatkan oleh Pen- duduk}

Beberapa informasi yang diperoleh merupakan data pengobatan empiris yang berhasil dikumpulkan di lapangan melalui wawancara dengan penduduk setempat. Data empiris merupakan data yang diperoleh berdasarkan pengalaman dan kebiasaan penduduk yang pernah menggunakannya ataupun berdasarkan resep yang diturunkan dari para pendahulu mereka. Meskipun ada beberapa jenis yang tidak memiliki informasi lengkap namun menurut penduduk lokal, mereka merasakan manfaat setelah mengonsumsi ramuan yang berasal dari pohon jenis tertentu. Ramuan ini biasanya merupakan campuran dari beberapa jenis tumbuhan yang berbeda. Umumnya informasi ini tidak disimpan dalam bentuk tulisan maupun dokumen resmi namun hanya diwariskan secara lisan dari mulut ke mulut saja.

Gambar 3 menunjukkan sebaran tingkat pendidikan responden serta bagaimana responden memperoleh pengetahuan tentang pengobatan tradisional yang sampai saat ini masih dipraktekkan di lokasi studi. Tingkat pendidikan 40 responden yang diwawancarai, masing-masing 20 responden dari Desa Gondowido (CA Gunung Picis) dan Desa Pupus (CA Gunung Sigogor), memiliki persentase yang hampir sama untuk jenjang pendidikan tingkat Sekolah Dasar, baik tidak lulus maupun lulus SD (ketidak lulusan siswa mencapai 70\% di Desa Gondowido dan 
80\% di Desa Pupus). Hanya sekitar 20\% responden pernah duduk di tingkat SMP dan sebanyak 30\% responden memiliki ijazah SMP.

Jenis-jenis yang disebutkan pada Tabel 2 (lima jenis) merupakan jenis pohon yang dimanfaatkan oleh penduduk di Desa Gondowido (CA Gunung Picis) dan Desa Pupus (CA Gunung Sigogor), Kabupaten Ponorogo untuk digunakan sebagai bahan ramuan obat-obatan.

Beberapa informasi yang dicantumkan pada jenis-jenis pohon berkhasiat obat yang ditemukan di Kabupaten Ponorogo (Tabel 2) diperoleh melalui kajian pustaka dan hasil wawancara dengan penduduk. Pada kenyataanya, beberapa jenis yang diketahui memiliki khasiat obat, namun belum dimanfaatkan oleh penduduk

Distribusi sumber pengetahuan tentang tumbuhan obat (Knowledge distribution on medicinal plants)

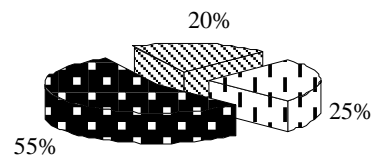

- Dari orang tua (From the eider)

Dari pengobat tradisional (From traditional healers)

Dari mulut ke mulut (Oral messages)

Desa Gondowido, Gunung Picis (Gondowido Village, Mt Picis) karena berbagai macam alasan, salah satu di antaranya adalah keterbatasan informasi dan aksesibilitas.

\section{Permasalahan Umum di Lapangan}

Berdasarkan pengamatan di lapangan, ada beberapa hal yang menjadi kendala penyebab lambannya kemajuan tentang pemanfaatan pohon berkhasiat obat, baik oleh masyarakat lokal yang ada di sekitar kawasan hutan cagar alam maupun masyarakat perkotaan di Kabupaten Ponorogo pada umumnya. Demikian juga dengan hilangnya beberapa jenis pohon berpotensi obat akibat berbagai macam kegiatan manusia. Problem tersebut secara rinci antara lain:

1. Kegiatan eksplorasi pohon berkhasiat obat yang tumbuh di hutan alam tidak

Distribusi sumber pengetahuan tentang tumbuhan obat (Knowledge distribution on medicinal plants)

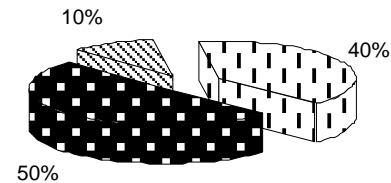

- Dari orang tua (From the eider)

\$ Dari pengobat tradisional (From traditional healers) ๑ Dari mulut ke mulut (Oral messages)

Desa Pupus, Gunung Sigogor (Pupus Village, Mt Sigogor)

Sebaran tingkat pendidikan responden (Distribution of respondent's level of education)

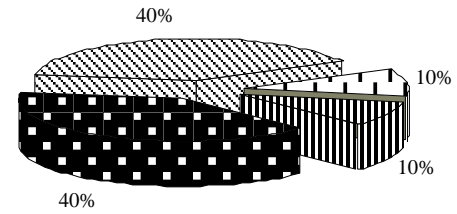

- Lulus SD (Graduate from elementary)

\$ Tidak lulus SD (Failed from elementary)

$\square$ Tidak lulus SMP (Failed from junior high school)

II Lulus SMP (Graduate from junior high school)

Gambar (Figure) 3. Sebaran tingkat pendidikan dan sumber pengetahuan tentang tumbuhan obat dari responden yang diwawancarai yang berasal dari Desa Gondowido, Gunung Picis dan Desa Pupus, Gunung Sigogor, Kabupaten Ponorogo, Provinsi Jawa Timur (Level of education and occupation of respondent from Gondowido village, Mt. Picis and Pupus village, Mt. Sigogor, Kabupaten Ponorogo, Provinsi Jawa Timur) 
Tabel (Table) 2. Daftar jenis pohon hutan yang sering dimanfaatkan oleh penduduk di Desa Pupus (CA Gunung Sigogor) dan Desa Gondowido (CA Gunung Picis), Kabupaten Ponorogo untuk bahan pengobatan (List of tree species oftenly used as medicinal plants by villagers in Pupus village (Mt Sigogor) and Gondowido village (Mt Picis), Ditrict of Ponorogo)

\begin{tabular}{|c|c|c|c|}
\hline No. & $\begin{array}{c}\text { Nama botani } \\
\text { (Botanical name) }\end{array}$ & $\begin{array}{c}\text { Suku } \\
\text { (Family) }\end{array}$ & $\begin{array}{l}\text { Tingkat dan jenis pemanfaatan } \\
\text { (Level and type of of use) }\end{array}$ \\
\hline 1. & Schima wallichii Korth. & Theaceae & $\begin{array}{l}\text { Sering dimanfaatkan dengan diambil buahnya. } \\
\text { Buah tua ditumbuk halus, lalu diseduh dengan air } \\
\text { panas dan diminum untuk mengurangi diare dan } \\
\text { sakit perut. }\end{array}$ \\
\hline 2. & Engelhardtia spicata Bl. & Juglandaceae & $\begin{array}{l}\text { Penduduk sering mengambil kulit batang yang } \\
\text { kemudian ditumbuk halus lalu dicampur air. } \\
\text { Campuran digunakan untuk mengobati gatal } \\
\text { dengan cara digosokkan di bagian kulit yang } \\
\text { gatal }\end{array}$ \\
\hline 3. & Persea odoratissima Kosterm. & Lauraceae & $\begin{array}{l}\text { Penduduik memanfaatkan daunnya untuk } \\
\text { mengobati bisul. Daun ditumbuk halus dan } \\
\text { campur sedikit air lalu ditempelkan pada bagian } \\
\text { yang sakit/bisul atau bengkak yang berisi nanah. }\end{array}$ \\
\hline 4. & Ganophyllum falcatum Bl. & Sapindaceae & $\begin{array}{l}\text { Jenis ini sering digunakan oleh masyarakat } \\
\text { dengan memanfaatkan kulit batangnya sebagai } \\
\text { obat penyubur rambut. Kulit batang ditumbuk } \\
\text { halus, campur air, dipakai untuk keramas }\end{array}$ \\
\hline 5. & Payena lerii Kurz. & Sapotaceae & $\begin{array}{l}\text { Daun dimanfaatkan untuk mengobati diare dan } \\
\text { sakit perut. Daun dikeringkan dan ditumbuk } \\
\text { halus, diseduh dengan air panas lalu diminum. }\end{array}$ \\
\hline
\end{tabular}

mudah karena kurangnya informasi tertulis yang ada di kedua lokasi pengamatan.

2. Eksplorasi menyangkut pohon-pohon hutan yang berpotensi sebagai bahan baku obat-obatan masih sangat minim. Contohnya, ada beberapa jenis yang ditemukan diketahui berpotensi untuk menyembuhkan penyakit namun demikian belum teruji kandungan bahan kimia aktifnya. Kalaupun ada informasi tentang pemanfaatan beberapa jenis pohon obat beserta kajian kandungan bahan kimia aktifnya, informasi ini tidak sampai ke masyarakat.

3. Adanya perubahan kondisi kawasan hutan akibat pembalakan liar dan perambahan hutan menyebabkan punahnya beberapa jenis tumbuhan langka yang masih belum dieksplorasi jenis dan kegunaannya.

4. Pada kawasan atau lokasi tertentu jumlah jenis pohon berkhasiat obat akan sangat tinggi namun belum semuanya dikenal, baik jenis maupun pemanfaatannya.

5. Sistem dokumentasi keanekaragaman jenis hayati yang dilakukan oleh instansi pemerintah setempat yang ada saat ini masih lemah.

6. Pemanfaatan dan pengembangan jenisjenis yang ditemukan masih sangat minim mengingat beberapa jenis berpotensi sebagai bahan baku obat masih belum diketahui secara luas oleh masyarakat.

\section{IV.KESIMPULAN DAN SARAN}

\section{A. Kesimpulan}

1. Berdasarkan hasil penelitian dan estimasi potensi jenis-jenis pohon berkhasiat obat di beberapa kawasan hutan di Kabupaten Ponorogo, terdapat sejumlah 12 jenis pohon. Dari 12 je- 
nis yang ada di Cagar Alam (CA) Gunung Sigogor dan Gunung Picis, hanya lima jenis yang dimanfaatkan oleh penduduk untuk bahan obat yaitu: puspa (Schima wallichii Korth.), morosowo (Engelhardtia spicata $\mathrm{Bl}$.), talesan (Persea odoratissima Kosterm.), mangir (Ganophyllum falcatum Bl.), dan kayu abang (Payena lerii Kurz.).

2. Cagar alam yang ada di kawasan hutan Kabupaten Ponorogo memiliki kekayaan jenis pohon berkhasiat obat cukup tinggi. Hal ini dibuktikan dengan nilai indeks penting (INP) tingkat pohon yang cukup tinggi untuk pasang (Castanopsis acuminatissima A.D.C.) yaitu $146,24 \%$ dan puspa (Schima walichii Korth.) yaitu 134,04\% untuk tingkat tiang. Namun demikian pengetahuan dan pemanfaatannya masih sangat kurang.

3. Sedikitnya jumlah jenis yang dimanfaatkan oleh penduduk lokal menunjukkan masih rendahnya tingkat pemanfaatan sumberdaya bahan baku obat yang berasal dari pohon-pohon yang tumbuh liar di hutan.

\section{B. Saran}

1. Provinsi Jawa Timur memiliki potensi yang cukup baik untuk dikembangkan sebagai sumber bahan baku obatobatan tradisional, terutama kawasan hutan cagar alam.

2. Mengingat adanya masyarakat yang masih memanfaatkan pohon yang berkhasiat obat berdasarkan pengalaman dan kebiasaan, nampaknya perlu dilakukan penelitian lebih lanjut menyangkut pengumpulan informasi sebanyak-banyaknya dari para tetua desa tentang kemungkinan adanya jenis pohon lain yang berpotensi sebagai bahan ramuan obat namun tidak terdapat di cagar alam.

3. Masyarakat juga diharapkan untuk melakukan upaya pelestarian terhadap jenis-jenis pohon, terutama yang dite- mukan di cagar alam untuk dipelihara dan dilestarikan.

4. Jenis-jenis yang sudah dimanfaatkan dan dibudidayakan oleh masyarakat sebaiknya diinformasikan kepada dinas kesehatan ataupun lembaga penelitian terkait setempat untuk selanjutnya dapat dikembangkan dan dilakukan kajian lebih mendalam termasuk uji kandungan bahan kimia aktifnya.

\section{DAFTAR PUSTAKA}

Amzu, E. dan Haryanto. 1991. Pelestarian Pemanfaatan Tumbuhan Obat di Indonesia. Proceeding "Pelestarian Pemanfaatan tumbuhan Obat dari Hutan Tropis Indonesia”. Editor: E.A.M. Zuhud. Jurusan Konservasi Sumberdaya Hutan, Fahutan IPB bekerjasama dengan Yayasan Pembinaan Suaka Alam dan Margasatwa Indonesia (The Indonesian Wildlife Fund). Bogor.

Bagian Botani Hutan. 1976. Daftar Nama Pohon-pohonan Jawa Barat. Laporan 219. Lembaga Penelitian Hutan. Bogor.

Bagian Botani Hutan. 1977. Daftar Nama Pohon-pohonan Jawa Tengah. Laporan 244. Lembaga Penelitian Hutan. Bogor.

Ditjen POM. 1991. Laporan Tahunan Ditjen POM. Direktorat Pengawasan Obat Tradisional 1991/1992. Jakarta.

Departemen Kesehatan Republik Indonesia. 1989. Vademekum Bahan Obat dan Makanan. Direktorat Jenderal Pengawasan Obat dan Makanan. Jakarta.

Chowwanapoonpohn, S., D. Buddasukh, dan M. Garson. 2005. Isolation of Pentacyclic Triterpenoid Compounds from Lithocarpus elegans (Bl.) Hatus. Ec Soep. By Electrocoagulation. ISHS Acta Horticulturae 677: III WOCMAP Congress on Medicinal and Aromatic Plants, Volume 3: Perspectives in Natural 
Product Chemistry. Web site: http: //www.actahort.org/members/show pdf?booknrarnr=677_2

Heyne, K. 1987. Tumbuhan Berguna Indonesia Vol. 1-4. Yayasan Sarana Wana Jaya. Jakarta.

Hutton, W. 1997. Tropical Herbs and Spices of Indonesia. Periplus Edition (HK) Ltd. Singapore.

Hadad, A. H dan O. Rostiana. 1991. Upaya pelestarian tumbuhan obat di Balittro. Proceeding "Pelestarian Pemanfaatan tumbuhan Obat dari Hutan Tropis Indonesia”. Editor: E.A.M. Zuhud. Jurusan Konservasi Sumberdaya Hutan, Fahutan IPB bekerjasama dengan Yayasan Pembinaan Suaka Alam dan Margasatwa Indonesia (The Indonesian Wildlife Fund). Bogor.

Jafarsidik, Y.S. dan M. Soetarto. 1980. Jenis-jenis Tumbuhan Obat di Beberapa Hutan di Jawa Timur dan Bali serta Pemanfaatan dan Pengembangannya. Laporan 36. Lembaga Penelitian Hutan. Bogor.

Jafarsidik, Y.S. dan S. Sutomo. 1986. Jenis-jenis Tumbuhan Obat dan Pengobatan Tradisional Penduduk di Daerah Tamito, Seram Selatan, Maluku. Buletin Peneltian Hutan 485: 19-29.

Kent, M. dan P. Coker. 1992. Vegetation Description and Analysis: A Practical Approach. CRC Press, Behalven Press.

Krebs, C. J. 1994. Ecology: The Experimental Analysis of Distribution and Abundance. Harper Collins College Publishers.

Krebs, C. J. 1999. Ecological Methodology. Jim Green.

Khan, M.R, M. Kihara, and A.D. Omoloso. 2001. Antimicrobial Activity of Castanopsis acuminatissima. Fitoterapia 72 (2): 174-176.

PROSEA. 2001. Plant Resources of South-East Asia 12: Medicinal and Poisonous Plants 12 (1, 2, 3). Edi- tor: J.L.C.H van Valkenburg and N. Bunyapraphastsara. Backhuys Publishers. Leiden.

Sastrapradja, D.S., S. Adisoemarto, K. Kartawinata, S. Sastrapradja, dan M. A. Rifa'i. 1989. Keanekaragaman Hayati untuk Kelangsungan Hidup Bangsa. Puslitbang Bioteknologi-LIPI.

Schmidt, F.H. and J. H. A Ferguson. 1951. Rainfall Types Based on Wet and Dry Period Ratios for Indonesian with Western New Guinea. Kementrian Perhubungan Jawatan Meteorologi dan Geofisika. Jakarta.

Sumarna, Y. 2001. Kajian Investasi dan Promosi Industri Tumbuhan Obat Hutan. Puslitbang Hutan dan Konservasi Alam. Bogor.

Schlemper, S.R. de M., V. Schlemper, D. da Silva, F. Cordeiro, A.B. Cruz, A.E. Oliveira, V. Cechinel-Filho. 2001. Antibacterial Activity of Persea cordata Stem Barks. Fitoterapia 72 (1): 73-75.

Safitri. 1995. Isolasi Alkaloida dari Kulit Batang Twpinia sphaerocarjia Hassk. Dalam Penelitian Tanaman Obat di beberapa Perghuruan Tinggi di Indonesia VII. Editor: L. Widowati, B. Wahjoedi, B. Dzulkarnain, Sa'roni, Adjirni, M.W. Winarno, D. Sundari. Pusat Penelitian dan Pengembangan Farmasi. Jakarta.

Tjitrosoepomo, G. 2005. Taksonomi Tumbuhan Obat-obatan. Gadjah Mada University Press. Yogyakarta. Whitmore, T.C. and I G.M. Tantra. 1986. Tree Flora of Indonesia. Check List for Jawa. Pusat Litbang Hutan. Bogor.

Widjayakusuma, H.M.H. 2000. Ensiklopedia Milenium Tumbuhan Berkhasiat Obat Indonesia. Prestasi Insan Indonesia. Jakarta.

Widjayakusuma, H., S. Dalimartha, dan A.S. Wirian. 1996. Tanaman Berkhasiat Obat di Indonesia. Jilid IV. Pustaka Kartini. Jakarta. 
Lampiran (Appendix) 1. Daftar nama jenis pohon (diameter di atas $10 \mathrm{~cm}$ ) hutan Cagar Alam Gunung Sigogor, Ponorogo, Jawa Timur (List of forest tree species in Mount Sigogor Nature Reserve, Ponorogo, East Java)

\begin{tabular}{|c|c|c|c|}
\hline No & Nama ilmiah (Scientific name) & Suku (Family) & Nama daerah (local name) \\
\hline 1 & Celtis cinammomum Lindl. & Ulmaceae & Klitik \\
\hline 2 & Elaeocarpus sphaericus K. Schum * & Tilliaceae & Gitri \\
\hline 3 & Elmerillia ovalis Dandy & Magnoliaceae & Cempaka hutan \\
\hline 4 & Engelhardia spicata Bl.* & Juglandaceae & Morosowo \\
\hline 5 & Euodia aromatica $\mathrm{Bl}$. & Rutaceae & Sampang \\
\hline 6 & Ganophyllum falcatum Bl. * & Sapindaceae & Mangir \\
\hline 7 & Gardenia sp. & Theaceae & Ampek \\
\hline 8 & Geunsia pentandra Merr. & Verbenaceae & Meniran \\
\hline 9 & Grewia laevigata & Tiliaceae & Urisan \\
\hline 10 & Lithocarpus elegans Bl. * & Fagaceae & Pasang \\
\hline 11 & Litsea odorifera T er B * & Anacardiaceae & Nyampuh \\
\hline 12 & Payena lerii Kurz * & Sapotaceae & Kayu Abang \\
\hline 13 & Peltophorum sp & Caesalpinae & Saga \\
\hline 14 & Persea odoratissima Kosterm * & Lauraceae & Talesan \\
\hline 15 & Pygeum parviflorum T et B * & Rosaceae & Nyampuh \\
\hline 16 & Radermachera gigantea Miq & Bignoniaceae & Dali \\
\hline 17 & Schima wallichii Korth * & Theaceae & Puspa \\
\hline 18 & Toona sinensis M. Roem * & Meliaceae & Suren \\
\hline 19 & Syzygium sp & Myrtaceae & Wasin \\
\hline 20 & Tarenna incuta $\mathrm{K}$ et $\mathrm{V}$ & Rubiaceae & Sikatan \\
\hline 21 & Turpinia sphaerocarpus Hassk * & Staphilacaceae & Cempaka \\
\hline
\end{tabular}

*) pohon berkhasiat obat (medicinal plants)

Sumber (Source): Hasil pengamatan di lapangan (Results from field observation)

Lampiran (Appendix) 2. Daftar nama jenis pohon (diameter di atas $10 \mathrm{~cm}$ ) hutan Cagar Alam Gunung Picis, Ponorogo, Jawa Timur (List of forest tree species in Mount Picis Nature Reserve, Ponorogo, East Java)

\begin{tabular}{llll}
\hline \multirow{2}{*}{ No } & \multicolumn{1}{c}{ Nama ilmiah (Scientific name) } & Suku (Family) & Nama daerah (local name) \\
\hline 1 & Castanopsis acuminatissima A.DC * & Fagaceae & Pasang rebung \\
2 & Engelhardia spicata Bl.* & Juglandaceae & Morosowo \\
3 & Euodia aromatica Bl. & Rutaceae & Sampang \\
4 & Gardenia sp & Theaceae & Ampek \\
5 & Helicia serrata Bl. & Protaceae & Kendung \\
6 & Laportea microstigma Gand & Urticaceae & Kemaduh \\
7 & Laportea stimulans & Urticaceae & Jelatang \\
8 & Lithocarpus elegans Bl. $*$ & Fagaceae & Pasang biasa \\
9 & Persea odoratissimea Kosterm * & Lauraceae & Talesan \\
10 & Schima wallichii Korth $*$ & Theaceae & Puspa \\
\hline
\end{tabular}

*) pohon berkhasiat obat (medicinal plants)

Sumber (Source): Hasil pengamatan di lapangan (Results from field observation) 
Lampiran (Appendix) 3. Komposisi jenis tingkat pohon dan tiang di hutan CA Gunung Sigogor, Kabupaten Ponorogo, Jawa Timur (Species composition at tree and pole stages in Mount Sigogor Nature Reserves, District of Ponorogo, East Java)

\begin{tabular}{|c|c|c|c|c|c|c|c|c|c|c|c|}
\hline No. & Nama jenis (Scientific name) & Suku (Family) & $\begin{array}{c}\text { Tingkat } \\
\text { pohon/tiang } \\
\text { (Tree or pole) }\end{array}$ & $\begin{array}{c}\text { Bidang dasar } \\
\text { (Basal area) } \\
\left(\mathrm{m}^{2}\right)\end{array}$ & $\begin{array}{c}\text { Jumlah } \\
\text { plot (Total } \\
\text { plot) } \\
\end{array}$ & $\begin{array}{c}\text { Jumlah ba- } \\
\text { tang (Total } \\
\text { stem) } \\
\end{array}$ & $\begin{array}{c}F \\
(\%)\end{array}$ & $\begin{array}{l}\text { FR } \\
\text { (\%) }\end{array}$ & $\begin{array}{l}\text { KR } \\
\text { (\%) }\end{array}$ & $\begin{array}{c}\text { DoR } \\
(\%)\end{array}$ & $\begin{array}{l}\text { INP } \\
(\%)\end{array}$ \\
\hline 1. & Elaeocarpus sphaericus K.Schum* & Elaeocarpaceae & Pohon (Tree) & 0,297 & 1 & 1 & 20 & 5,88 & 5,00 & 6,93 & 17,81 \\
\hline 2. & Engelhardia spicata $\mathrm{Bl}^{*}$ & Juglandaceae & Pohon (Tree) & 1,190 & 2 & 2 & 40 & 11,76 & 10,00 & 27,75 & 49,52 \\
\hline 3. & Gardenia sp. & Rubiaceae & Pohon (Tree) & 0,108 & 1 & 1 & 20 & 5,88 & 5,00 & 2,52 & 13,40 \\
\hline 4. & Lithocarpus elegans Bl. & Fagaceae & Pohon (Tree) & 0,176 & 2 & 2 & 40 & 11,76 & 10,00 & 4,10 & 25,87 \\
\hline 5. & Litsea adorifera $\mathrm{T}$ et $\mathrm{B}$ & Lauraceae & Pohon (Tree) & 0,198 & 3 & 5 & 60 & 17,65 & 25,00 & 4,62 & 47,26 \\
\hline 6. & Payena lerii Kurz* & Sapotaceae & Pohon (Tree) & 0,858 & 3 & 3 & 60 & 17,65 & 15,00 & 20,01 & 52,66 \\
\hline 7. & Persea odoratissima Kosterm* & Lauraceae & Pohon (Tree) & 1,399 & 4 & 5 & 80 & 23,53 & 25,00 & 32,63 & 81,16 \\
\hline 8. & Radermachera gigantea Miq & Bignoniaceae & Pohon (Tree) & 0,062 & 1 & 1 & 20 & 5,88 & 5,00 & 1,45 & 12,33 \\
\hline 9. & Engelhardia spicata $\mathrm{Bl} .{ }^{*}$ & Juglandaceae & Tiang (Pole) & 0,033 & 2 & 2 & 40 & 11,76 & 10,53 & 9 & 31,29 \\
\hline 10. & Ganophyllum falcatum Bl.* & Sapindaceae & Tiang (Pole) & 0,032 & 2 & 2 & 40 & 11,76 & 10,53 & 8 & 30,73 \\
\hline 11. & Gardenia sp. & Rubiaceae & Tiang (Pole) & 0,038 & 2 & 2 & 40 & 11,76 & 10,53 & 10 & 32,32 \\
\hline 12. & Lithocarpus elegans $\mathrm{Bl}$. & Fagaceae & Tiang (Pole) & 0,034 & 2 & 2 & 40 & 11,76 & 10,53 & 9 & 31,26 \\
\hline 13. & Litsea odorifera $\mathrm{T}$ et $\mathrm{B}$ & Lauraceae & Tiang (Pole) & 0,057 & 3 & 3 & 60 & 17,65 & 15,79 & 15 & 48,48 \\
\hline 14. & Payena lerii Kurz* & Sapotaceae & Tiang (Pole) & 0,024 & 1 & 1 & 20 & 5,88 & 5,26 & 6 & 17,48 \\
\hline 15. & Persea odoratissima Kosterm* & Lauraceae & Tiang (Pole) & 0,061 & 2 & 3 & 40 & 11,76 & 15,79 & 16 & 43,65 \\
\hline 16. & Schima wallichii Korth* & Theaceae & Tiang (Pole) & 0,023 & 1 & 1 & 20 & 5,88 & 5,26 & 6 & 17 \\
\hline 17. & Syzygium sp. & Myrtaceae & Tiang (Pole) & 0,023 & 1 & 1 & 20 & 5,88 & 5,26 & 6 & 17,21 \\
\hline 18. & Turpinia sphaerocarpus Hassk* & Staphylaceae & Tiang (Pole) & 0,054 & 1 & 2 & 20 & 5,88 & 10,53 & 14 & 30,66 \\
\hline
\end{tabular}

Keterangan (Remarks): *pohon berkhasiat obat (medicinal plants) 

stages in Mount Picis Nature Reserves, District of Ponorogo, East Java)

\begin{tabular}{|c|c|c|c|c|c|c|c|c|c|c|c|}
\hline No. & Nama jenis (Scientific name) & Suku (Family) & $\begin{array}{c}\text { Tingkat } \\
\text { pohon/tiang } \\
\text { (Tree or pole) }\end{array}$ & $\begin{array}{c}\text { Bidang dasar } \\
\text { (Basal area) } \\
\quad\left(\mathrm{m}^{2}\right)\end{array}$ & $\begin{array}{c}\text { Jumlah } \\
\text { plot (Total } \\
\text { plot) }\end{array}$ & $\begin{array}{c}\text { Jumlah } \\
\text { ba-tang } \\
\text { (Total } \\
\text { stem) } \\
\end{array}$ & $\begin{array}{c}F \\
(\%)\end{array}$ & $\begin{array}{l}\text { FR } \\
(\%)\end{array}$ & $\begin{array}{l}\mathrm{KR} \\
(\%)\end{array}$ & $\begin{array}{c}\text { DoR } \\
\text { (\%) }\end{array}$ & $\begin{array}{l}\text { INP } \\
(\%)\end{array}$ \\
\hline 1. & Castanopsis acuminatissima A.DC* & Fagaceae & Pohon (Tree) & 1,333 & 3 & 6 & 100 & 33,33 & 50,00 & 62,91 & 146,24 \\
\hline 2. & Engelhardtia spicata Bl.* & Juglandaceae & Pohon (Tree) & 0,456 & 1 & 1 & 33,33 & 11,11 & 8,33 & 21,52 & 40,96 \\
\hline 3. & Helicia serrata $\mathrm{Bl}$. & Proteaceae & Pohon (Tree) & 0,038 & 1 & 1 & 33,33 & 11,11 & 8,33 & 1,79 & 21,24 \\
\hline 4. & Lithocarpus elegans Bl.* & Fagaceae & Pohon (Tree) & 0,096 & 1 & 1 & 33,33 & 11,11 & 8,33 & 4,53 & 23,97 \\
\hline 5. & Persea odoratissima Kosterm* & Lauraceae & Pohon (Tree) & 0,065 & 1 & 1 & 33,33 & 11,11 & 8,33 & 3,07 & 22,51 \\
\hline 6. & Schima wallichii Korth* & Theaceae & Pohon (Tree) & 0,131 & 2 & 2 & 66,67 & 22,22 & 16,67 & 6,18 & 45,07 \\
\hline 7. & Castanopsis acuminatissima A.DC* & Fagaceae & Tiang (Pole) & 0,073 & 2 & 3 & 66,67 & 25,00 & 25,00 & 33,64 & 83,64 \\
\hline 8. & Engelhardtia spicata $\mathrm{Bl} .^{*}$ & Juglandaceae & Tiang (Pole) & 0,012 & 1 & 1 & 33,33 & 12,50 & 8,33 & 5,53 & 26,36 \\
\hline 9. & Laportea microstigma Gand & Urticaceae & Tiang (Pole) & 0,013 & 1 & 1 & 33,33 & 12,50 & 8,33 & 5,99 & 26,82 \\
\hline 10. & Lithocarpus elegans Bl.* & Fagaceae & Tiang (Pole) & 0,018 & 1 & 1 & 33,33 & 12,50 & 8,33 & 8,29 & 29,13 \\
\hline 11. & Schima wallichii Korth* & Theaceae & Tiang (Pole) & 0,101 & 3 & 6 & 100 & 37,50 & 50,00 & 46,54 & 134,04 \\
\hline
\end{tabular}

